\title{
Back to the past: gains and losses in Brazilian society
}

\author{
Celi Scalon ${ }^{1,2^{*}}$, André Junqueira Caetano ${ }^{3}$, Hugo Chaves $^{4}$ and Luana Costa ${ }^{1}$
}

\author{
*Correspondence: celiscalon@ \\ gmail.com \\ ${ }^{1}$ Federal University of Rio de Janeiro \\ (UFRJ), Rio de Janeiro, Rio de \\ Janeiro, Brazil \\ 2University of Coimbra \\ (CES-Universidade de Coimbra), \\ Coimbra, Portugal \\ Full list of author information is \\ available at the end of the article
}

\begin{abstract}
During the first 15 years of the twenty-first century, Brazil's economic growth and public policies were in the center of the debate on the growing "new middle class." This new middle class is defined by people's household income between the upper 10th percentile and the median (Neri, A Nova Classe Média, 2008). Although there has been a consensus about the increase in consumption and the improvement of living conditions for a significant proportion of the population, there is less agreement about the decline in inequality and the change in class distribution. Previous work was directed at challenging the very idea that Brazil had become a middle-class country during the first decade of this century, basically weighting class distribution against income distribution. In this article, we aim to step into the income distribution debate using six income groups as proportions of the median household per-capita income. Our data source is the National Household Sample Survey (PNAD-IBGE/Brazil) in 2001, 2008, and 2015. We analyze groups' income distribution and characteristics using multinomial logistic models to take into account the effects of socioeconomic variables. We argue that there is significant stability in groups' income structure during the period, revealing their resistance to inequalities (similar to the findings in the works of Piketty and Souza). We also indicate that the odds of being included in the upper-income categories are quite unequal, considering socioeconomic variables. Finally, we point out that the gains observed from 2001 to 2008 had faded by 2015 when the odds of being included in the upper-income categories were remarkably similar to those of 2001.
\end{abstract}

Keywords: Inequalities, Income, Stratification, Middle class

\section{Introduction}

In 2008, Marcelo Neri stated that Brazil had become a middle-class country, as half of the population fell into the group with household income between the median and the upper $10 \%$. There was a heated debate around this issue, to the point that went outside academia and reached the public sphere, appearing in newspapers, magazines, and television. In general terms, the idea was that a new middle class emerged due to a rise in consumption, stemming from increasing income, which enabled individuals to purchase goods that only wealthier groups could afford in the past. Consequently, there was a popular opinion that Brazil had become a country in which the majority of households belonged to the middle class. This debate was fueled, to no small extent, by academic

(c) The Author(s). 2021 Open Access This article is licensed under a Creative Commons Attribution 4.0 International License, which permits use, sharing, adaptation, distribution and reproduction in any medium or format, as long as you give appropriate credit to the original author(s) and the source, provide a link to the Creative Commons licence, and indicate if changes were made. The images or other third party material in this article are included in the article's Creative Commons licence, unless indicated otherwise in a credit line to the material. If material is not included in the article's Creative Commons licence and your intended use is not permitted by statutory regulation or exceeds the permitted use, you will need to obtain permission directly from the copyright holder. To view a copy of this licence, visit http://creativecommons.org/licenses/by/4.0/. 
works that define classes partially or exclusively on the basis of monetary income or access to consumption (Neri 2008; Souza and Lamounier 2010; Oliveira 2010).

In the first 15 years of the twenty-first century, Brazil has undergone considerable economic growth, which, coupled with a decrease in income inequality, programs of direct cash transfer, credit expansion, and economic stabilization, resulted in increased income and improved living standards for a large number of families (Barros et al. 2010). In this context, Neri (2008) demonstrated a decline in the number of lowincome and a correlated increase in the number of families with intermediate-level household income-the so-called "new middle class."

Nonetheless, if there was a certain consensus about the increase in consumption and the improvement of living conditions, mainly for those in lower classes, then there were serious doubts about inequality reduction (Caetano and Dias 2018); Ferreira and Caetano 2015; Souza and Medeiros 2015; Santos Pinto and Caetano 2013; Souza 2010). We disputed the middle-class expansion narrative all along, arguing that regardless of the increase in income and consumption, there was no change in the class structure from the sociological perspective (Scalon 2013a, b; Scalon and Salata 2012, 2013; Salata and Scalon 2013, 2015; Salata, 2016; Scalon and Oliveira 2018; Caetano and Dias 2018; Ferreira and Caetano 2015). However, the claim that significantly changes in the income distribution toward lower inequality lingered, despite the fact that the class structure remained unaltered. The question then became whether this was the case.

In this article, we address this question by analyzing data from the National Household Sample Survey (PNAD-IBGE/Brazil) in 2001, 2008, and 2015, considering individuals between 24 and 65 years old. The selection of these three specific years is not random. Indeed, 2001, 2008, and 2015 were meaningful years for the Brazilian economy and society: 2001 marked the beginning of the country's economic growth and other emerging economies, the global financial and economic crisis hit the world in 2008, and finally, in 2015, Brazil became immersed in a deep economic crisis (Lélis et al. 2019; Serrano and Summa 2018).

This study is based on income groups (Li 2017) defined by proportions above and below the median per-capita household income in each survey year. Therefore, the groups are defined by relative income, which allows for the analysis of the relative inequalities among the six categories named by categories named by Li (2017): very rich (401\% above the median and higher), rich (201-400\%), upper-middle class (126-200\%), lower-middle class (76-125\%), vulnerable (26-75\%), and extremely poor (25\% or less). As we are using Brazilian household sampling and it is known that the top income strata can be underrepresented in probabilistic sampling, it is important to keep in mind that the "very rich" and "rich" layers comprise the majority of the upper whitecollar sector, such as professionals, entrepreneurs, and petite bourgeoisie. Important works on this theme have used income tax data as a way to avoid this problem, but such data are not available to us. Nevertheless, it is worth pointing out that even the data from tax returns have issues due to tax evasion or tax avoidance. In addition, in Brazil, tax data are classified as information, and only a few researchers have access to them. ${ }^{1}$

\footnotetext{
${ }^{1}$ Access to tax information is not open in Brazil and is granted to few researchers linked to the Brazilian government agency, the Institute for Applied Economic Research (IPEA)
} 
Be that as it may, we can place the analysis of very top income groups alongside other income groups as categories that can be understood as proxies of strata. In this sense, we consider that the study of income as a continuous variable neither would bring novelty to the debate nor would reflect the stratification system, which can reveal if the lower-income categories had experienced upward mobility, as argued by Neri (2008, 2010).

In this regard, a note of caution is in place. We do not aim to explain the change in the actual levels of income during the period observed but rather to comparatively grasp the trajectory of these groups. Thus, we focus on the examination of the sociodemographic variables and associative patterns that have a greater influence on the odds of belonging to a given income group.

The distribution of the six income groups in the 3 years shown in Fig. 1 registers a slightly decreasing tendency in the proportion of families in the two upper categories and a small increase in the two medium categories. This finding contradicts some of the expected results, as the literature on the rise in the middle class in Brazil during the last decade related it to the upward mobility of those in the bottom of the income distribution and not to a downward movement of those occupying the upper categories. What stands out is the stable continuity of Brazil's income structure, as the shifts observed are in the range of 2 to $4 \%$ from 2001 to 2015.

\section{Income categories over the years}

In his article, Li (2017) indicates the Chinese aspiration for reaching an income structure with the shape of an olive, which would reflect a distribution in which the two medium categories are larger than the two categories at the top and the two at the bottom. That olive-shape income distribution, according to the author, means to escape the middle-income trap, considering elements of social justice. Furthermore, economically, the middle-income groups are at the core of the consolidation of a mass consumption society. From this perspective, it can be said that Brazil appears to be on its way to

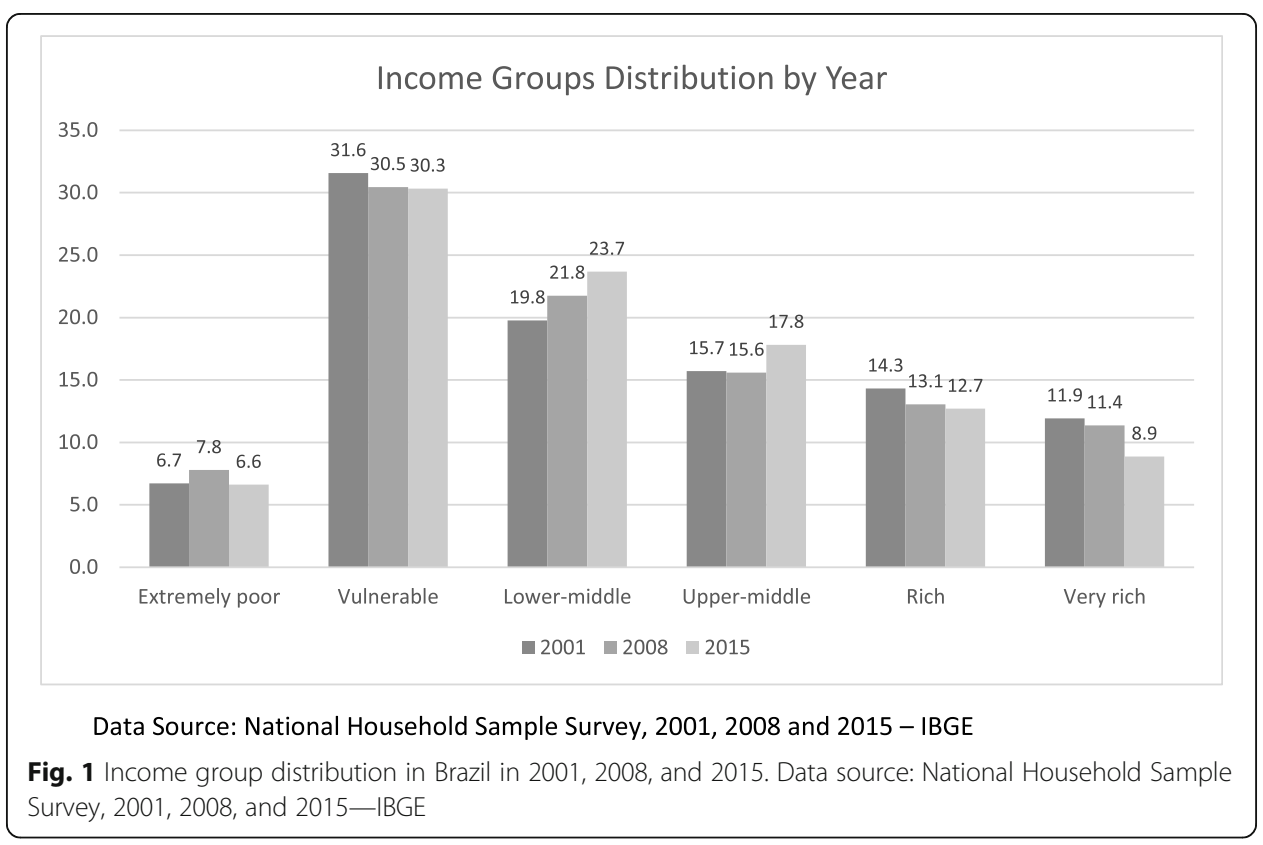


such an income structure, as in 2015, the lower- and upper-middle-class groups combined were larger than the bottom and top two combined.

It is important to pay attention to the changes in the values of household income during this period, as shown in Table 1.

Nevertheless, it is not possible to compare the values per se, considering that we are working with a time lag of 7 years. In this case, instead of analyzing the median values for household income, we can apply, as a comparable measure, the minimum salary for each year; the values were $2001, R \$ 180.00 ; 2008, R \$ 415.00$; and 2015 , $R \$ 788.00$. Thus, we can observe the equivalence of the median values in minimum salaries ratios. It is important to emphasize that there is a certain stability in the numbers; however, from 2001 to 2008, the two lower-income groups experienced reduced gains, which were lost in the following 7 years (2008-2015). All the other groups experienced losses from 2001 to 2015, except the very rich group, which received gains from 2008 to 2015. However, these reductions in the rates cannot be understood as losses, as they can imply that in 2008, the minimum salary was proportionally higher than those in 2001 and 2015. Moreover, we observe that the distance between categories decreased in 2008. In any case, these ratios show the differences between groups' incomes (Table 2).

If the changes found in the proportional distribution of the income groups during the period are small, then the same does not apply with regard to educational achievement measured in years of schooling. There is an unprecedented expansion of education in Brazil from 2001 to 2015, which is observed in each income group and reflects the near universalization of the primary education and intense expansion of secondary education, as well as the persistence of inequality in access to higher education (Silva and De Oliveira 2019) (Fig. 2).

In 2001, the Brazilian median years of schooling was 7 years, which indicates that half of the population had not finished middle school and that attending high school was a privilege of the two wealthier groups. Another noteworthy trait is that there was a 3schooling-years difference between the lower- and upper-middle-income groups, representing those who had not and those who had concluded middle school, respectively. As observed, in each survey, it is possible to apprehend a descriptive correlation between income level and educational level.

Seven years later, in 2008, the median for the years of schooling increased to nine, corresponding to the completion of middle school. The lower-middle-income group achieved a median of 9 years of schooling, improving by 3 years compared to 2001 . However, in 2015, this group presented the same median, while the median for the

Table 1 Median monthly household income

\begin{tabular}{llll}
\hline Income groups & $\mathbf{2 0 0 1}$ & $\mathbf{2 0 0 8}$ & $\mathbf{2 0 1 5}$ \\
\hline Extremely poor & $R \$ 94.00$ & $R \$ 290.00$ & $R \$ 460.00$ \\
Vulnerable & $R \$ 339.00$ & $R \$ 800.00$ & $R \$ 1400.00$ \\
Lower-middle & $R \$ 652.00$ & $R \$ 1360.00$ & $R \$ 2400.00$ \\
Upper-middle & $R \$ 1033.00$ & $R \$ 2053.00$ & $R \$ 3500.00$ \\
Rich & $R \$ 1790.00$ & $R \$ 3300.00$ & $R \$ 5600.00$ \\
Very rich & $R \$ 4800.00$ & $R \$ 7350.00$ & $R \$ 15988.00$ \\
Median & $R \$ 701.00$ & $R \$ 1315.00$ & $R \$ 2388.00$ \\
\hline
\end{tabular}

Data source: National Household Sample Survey, 2001, 2008, and 2015-IBGE 
Table 2 Proportion of minimum salary by income group in 2001, 2008, and 2015

\begin{tabular}{llll}
\hline Income groups & $\mathbf{2 0 0 1}$ & $\mathbf{2 0 0 8}$ & $\mathbf{2 0 1 5}$ \\
\hline Extremely poor & 0.52 & 0.70 & 0.58 \\
Vulnerable & 1.88 & 1.93 & 1.78 \\
Lower-middle & 3.62 & 3.28 & 3.05 \\
Upper-middle & 5.74 & 4.95 & 4.44 \\
Rich & 9.94 & 7.95 & 7.11 \\
Very rich & 26.67 & 17.71 & 20.29 \\
Median & 3.89 & 3.17 & 3.03 \\
\hline
\end{tabular}

Data source: National Household Sample Survey, 2001, 2008 and 2015-IBGE

country increased to 11 years. It is also important to highlight that 2008 is the year that a gap between the top two categories appeared, as the entrance into and completion of a college education is a characteristic more associated with the very rich group.

Looking at the year 2015, we can note that the two groups that benefited most from the Brazilian expansion of education level were the vulnerable and extremely rich groups, both adding 4 years to their respective medians. However, the vulnerable group attained a median number of years of schooling equivalent to middle school completion in the time when the value of middle school degree had considerably declined due to the massive diffusion of such diplomas throughout Brazilian society. Conversely, the very rich group reached the highest education achievement in Brazilian history, as the difference between the median of this group and the others was the greatest.

Despite the significant improvement in mass education, it is possible to claim that the Brazilian path was toward strengthening the advantages of the most privileged group, rather than reducing the educational gap. The bottom group that benefitted the most reached an educational level that has lost value in the labor market. As a

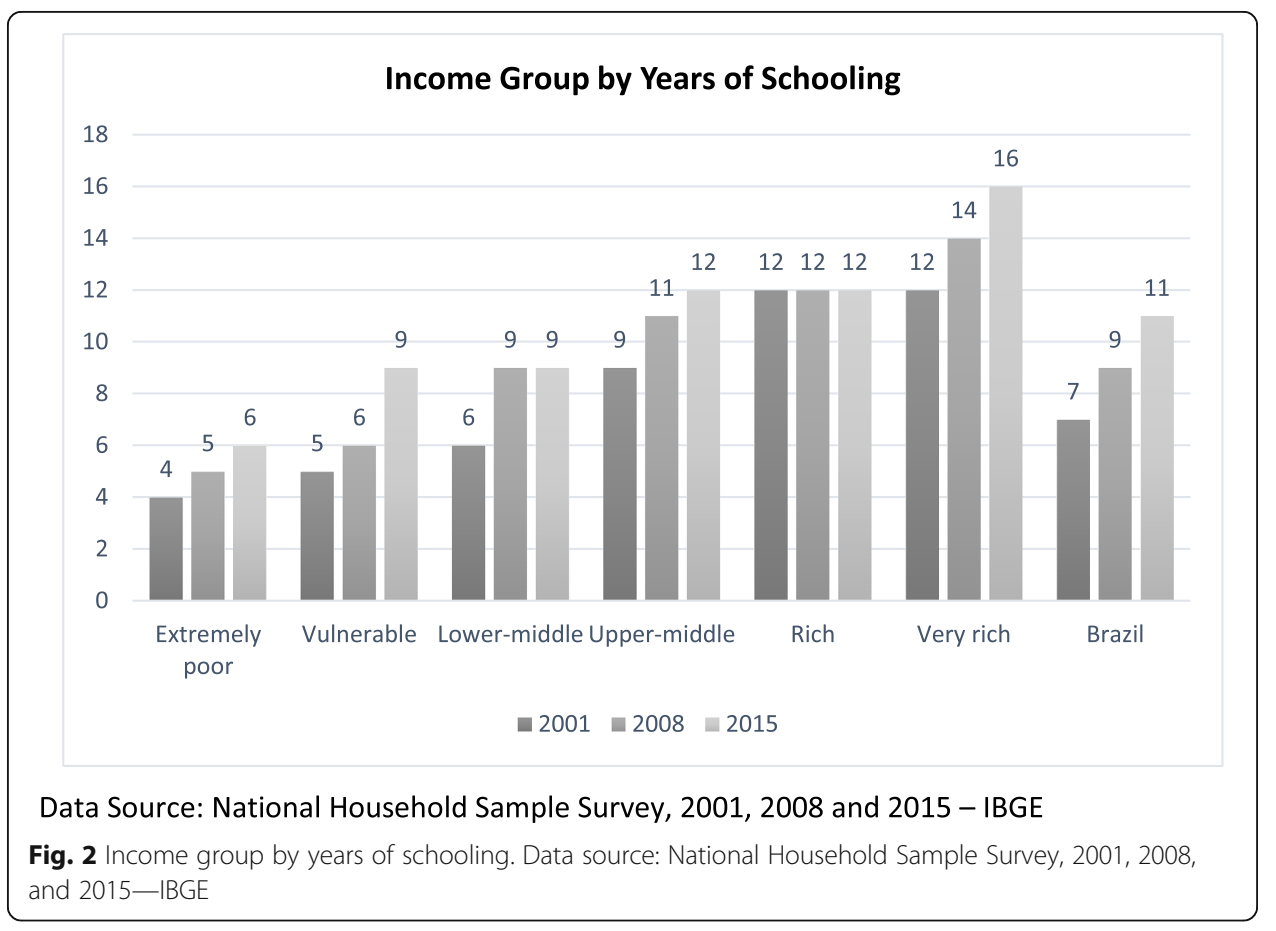


consequence, individuals who achieved the middle level were not guaranteed qualified and better-paid occupations any more in the twenty-first century. In other words, the observed increase in schooling represents an absolute or gross increase, which does not indicate a tendency that would enhance upward mobility.

Another crucial aspect of Brazil's social structure is racial inequality, and as Fig. 3 plainly shows that, while white individuals prevail in the top income groups, black individuals are the majority in the bottom income groups. Contrary to the changes found in the proportional distribution of families and individuals among the income groups between 2001 and 2015, there is visible stability in racial composition within groups during the observed period. The proportion of black people remains about the same in all six groups in the 3 years of the survey, which indicates that in spite of the general changes, black people cannot escape from the bottom income groups. It should be noted though, overall, there is an increase in the proportion of blacks, which stems from a change in the cultural and symbolic willingness to self-declare as black in Brazil (Silva and Leão 2012). However, as far as racial composition is concerned, there is no indication of any weakening trend of the historical income inequality between whites and blacks.

Because Brazil has large spatial variation and cultural heterogeneity, it is critical to take into account regional factors. The regional inequalities that were at the core of the sociological literature until the 1980s still present great explanatory power for understanding the country's disparities (Araújo and Flores 2017). In this regard, the dimension of the regional imbalance and unevenness is clear-cut when comparing the Southeast to the Northeast region, the two most populated regions in the country (Fig. 4). Indeed, the Northeast is the only region that has at least half of its population in the extremely poor and vulnerable groups in the 3 survey years. Another trait that stands out is that the two

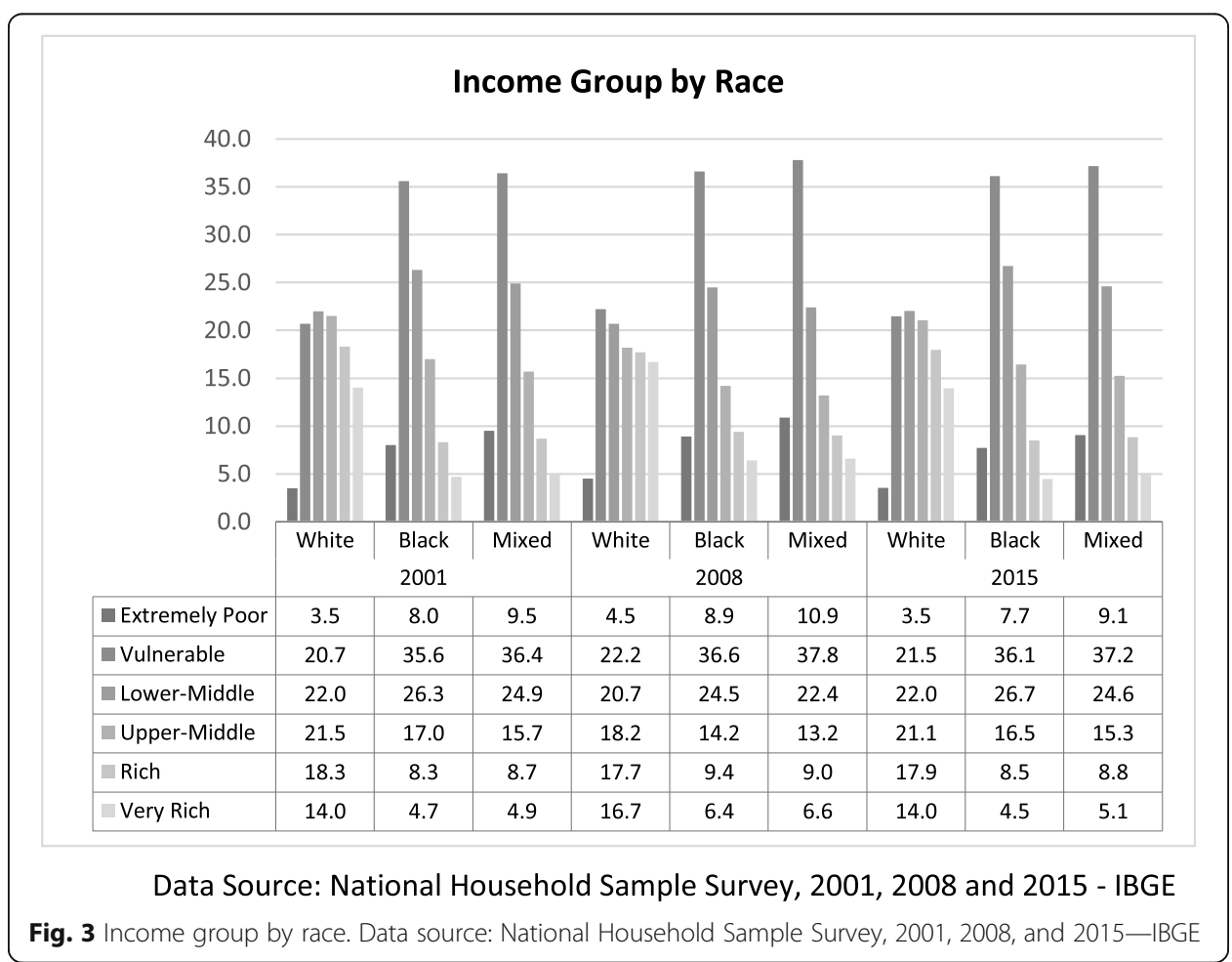




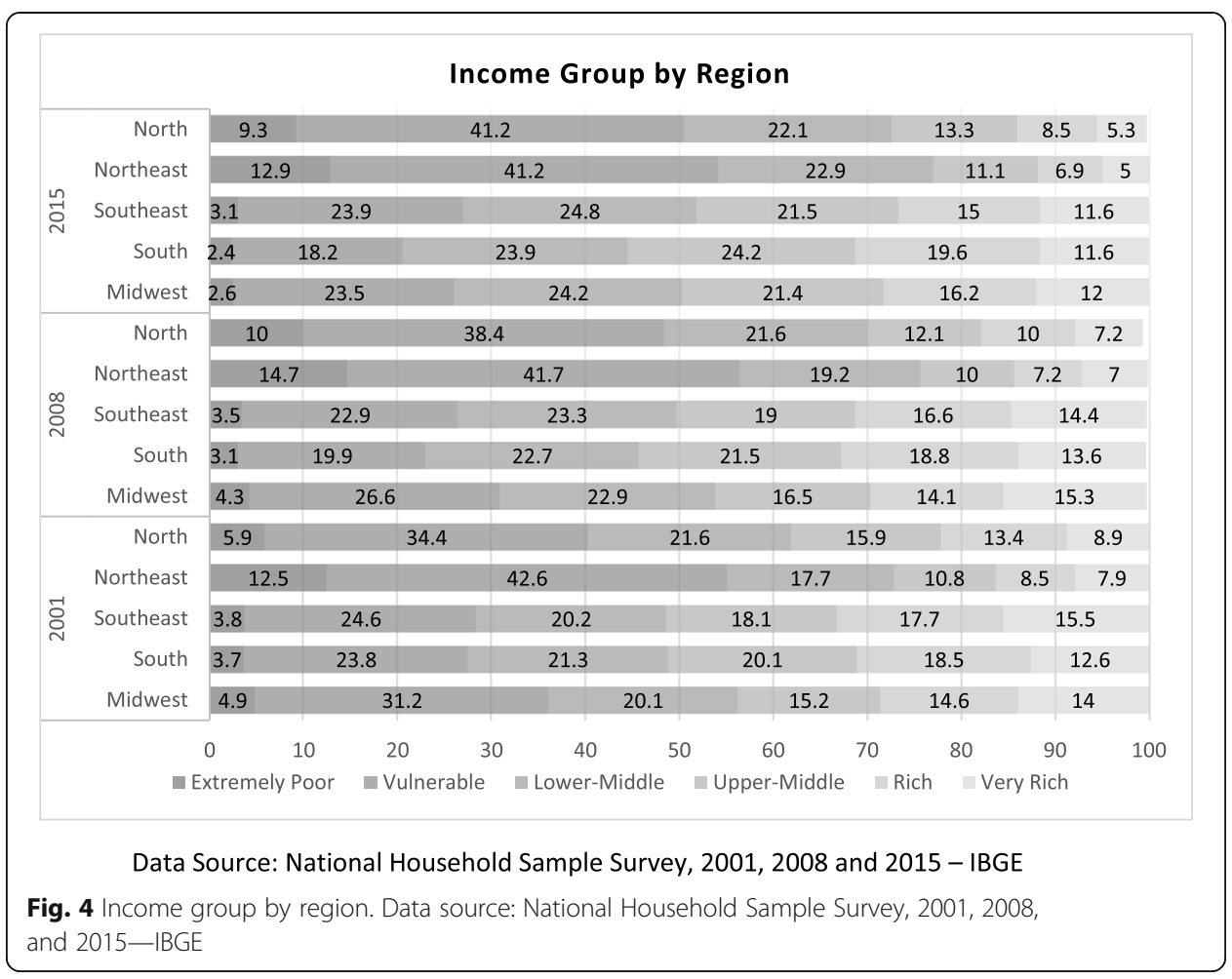

bottom groups grew in the North income structure from 2001 to 2015, while they were stable or decreased in all the other regions.

Along with the regional factor, another spatial element of social stratification for relative income groups is the difference between urban and rural areas. In addition to the considerable income gap in favor of the urban population, the relative income approach reveals the fact that the majority of rural dwellers fell into the two poorest income

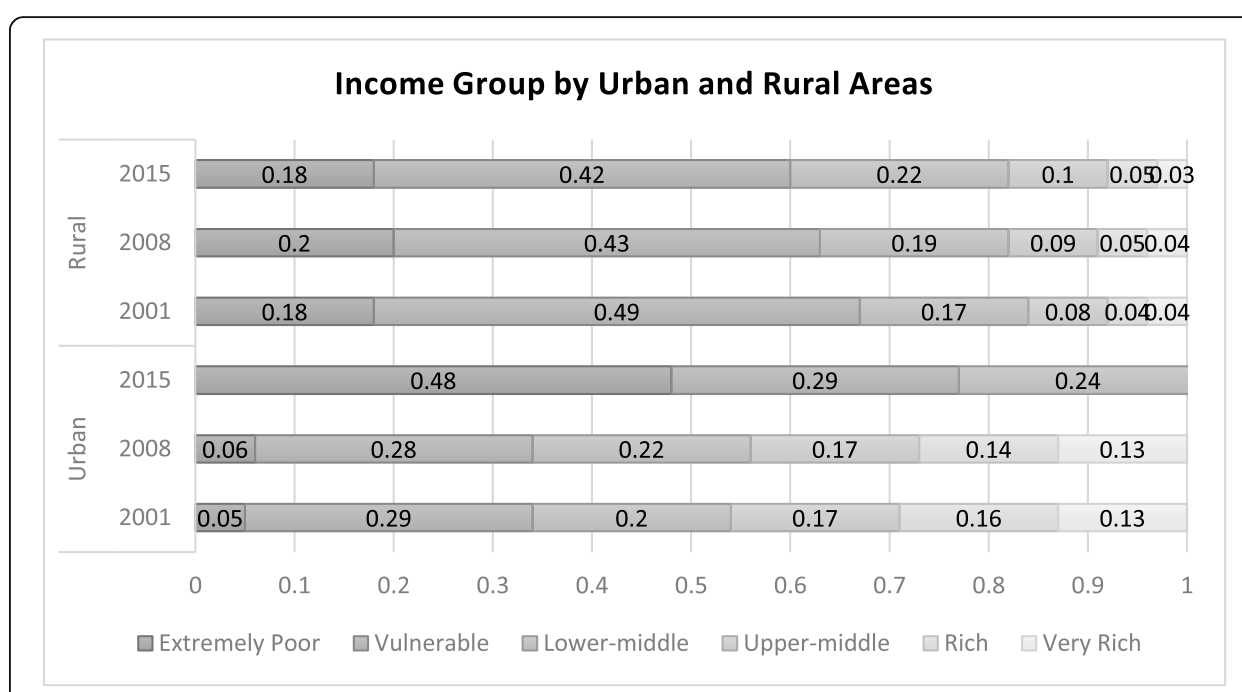

Data Source: National Household Sample Survey, 2001, 2008 and 2015 - IBGE

Fig. 5 Income group by urban and rural areas. Data source: National Household Sample Survey, 2001, 2008, and 2015-IBGE 
groups. The two bottom groups represent at least $60 \%$ of the rural population in the 3 years studied, while the two top income groups do not even reach $10 \%$. In sum, rural families are primarily in lower-income groups (Fig. 5).

\section{Modeling change and stability in time ${ }^{2}$}

Table 3 presents the coefficients, statistical significance, and odds ratios (ORs) of the model fitting the 2001 data.

Controlling for the covariates in the model, an additional year of age decreases the odds of being in each of the five groups relative to the very rich group, varying by $9 \%$ for the very poor group to $1 \%$ for the rich group.

The effect of the variable sex is more sizeable compared to that of age. The odds of women being in the extremely poor group are 93\% higher than those for men. The effect decreases for other groups, and the coefficients are statistically significant up to the upper-middle group, i.e., the odds of females being in the vulnerable relative to the very rich group are $57 \%$ higher than those for males, $31 \%$ higher for the lower-middle group, and $31 \%$ higher for the upper-middle group.

For the variable race, the odds of blacks being in the extremely poor group relative to the very rich group are 3.2 times higher than those for white people, 2.7 times higher for those in the vulnerable group, 2.3 times higher for those in the lower-middle group, 1.9 times higher for those in the upper-middle group, and 0.37 times higher, or 37\% higher, for those in the rich group. Among the three ascribed variables, the effect of race is the strongest. Suggestively, it diminishes as one goes up in the ladder of the relative income groups.

Each additional year of schooling decreases the odds of being in an extremely poor group relative to the very rich group by $40 \%$. This figure is $35 \%$ for the vulnerable group, $29 \%$ for the lower-middle group, $22 \%$ for the upper-middle group, and $10 \%$ for the rich group. Although the magnitude of the gap between each of the five groups and the very rich group declines from the extremely poor to the richest, these results indicate that education is an important asset for reducing inequality.

The coefficients of the variable region are statistically significant for the extremely poor, vulnerable, and lower-middle groups. The odds of Northeasterners being in the extremely poor group relative to the very rich group are 6.2 times higher than the odds for Southeastern dwellers, three times higher for those in the vulnerable group, and 1.7 times higher for those in the lower-middle group. As far as the extremely poor and vulnerable groups in 2001 are concerned, region has the largest effect in holding down individuals in these groups relative to the very rich group but is steeper for the extremely poor group and smoother for the lower-middle group.

Finally, regarding 2001, the coefficient of area of residence is not statistically significant for the lower-middle group. For the other groups, it has opposite effects for the two groups below and two groups above the lower-middle group. The odds of rural dwellers being in the extremely poor group relative to the very rich group are 2.3 times higher than the odds for urban dwellers, and 1.25 times higher in the vulnerable group. Conversely, compared to the very rich group, the odds for the upper-middle and rich groups are $37 \%$ and $47 \%$ lower, respectively. This finding indicates that individuals in

${ }^{2}$ See the Appendix for data and methods 
Table 3 Multinomial logistic regression of selected variables on the relative income groups-Northeast (NE) and Southeast (SE) regions, Brazil, 2001

\begin{tabular}{|c|c|c|c|c|c|c|c|c|c|c|}
\hline \multirow{3}{*}{$\begin{array}{l}\text { Intercept and } \\
\text { covariates }\end{array}$} & \multicolumn{10}{|c|}{ Income group ${ }^{a}$} \\
\hline & \multicolumn{2}{|c|}{ Extremely poor } & \multicolumn{2}{|c|}{ Vulnerable } & \multicolumn{2}{|c|}{ Lower-middle } & \multicolumn{2}{|c|}{ Upper-middle } & \multicolumn{2}{|l|}{ Rich } \\
\hline & $b$ & OR & $b$ & OR & $B$ & OR & $b$ & OR & $b$ & OR \\
\hline Intercept & $7.015^{*}$ & - & $7.666^{*}$ & - & $5.979 *$ & - & $4.435^{*}$ & - & $1.755^{*}$ & - \\
\hline Age & $-0.096^{*}$ & .908 & $-0.071^{*}$ & .932 & $-0.040^{*}$ & .960 & $-0.025^{*}$ & .976 & $-0.006^{*}$ & .994 \\
\hline Sex: female (ref: male) & $0.656^{*}$ & 1.928 & $0.453^{*}$ & 1.574 & $0.267^{*}$ & 1.306 & $0.125^{*}$ & 1.133 & .034 & 1.035 \\
\hline Race: black (ref: white) & $1.155^{*}$ & 3.173 & $1.007^{*}$ & 2.737 & $0.841^{*}$ & 2.318 & $0.632^{*}$ & 1.882 & $0.313^{*}$ & 1.367 \\
\hline Years of schooling & $-0.505^{*}$ & .603 & $-0.423^{*}$ & .655 & $-0.344^{*}$ & .709 & $-0.249^{*}$ & .780 & $-0.101^{*}$ & .904 \\
\hline Region: NE (ref: SE) & $1.832^{*}$ & 6.245 & $1.088^{*}$ & 2.968 & $0.535^{*}$ & 1.708 & .000 & 1.000 & -.004 & .996 \\
\hline Area: rural (ref: urban) & $0.832^{*}$ & 2.298 & $0.225^{*}$ & 1.253 & -.065 & .937 & $-0.463^{*}$ & .630 & $-0.644^{*}$ & .525 \\
\hline
\end{tabular}

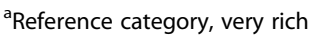

*Statistically significant at $p$ value $<0.01$

these two groups living in rural areas tend to be far wealthier than the rural inhabitants in the extremely poor and vulnerable groups.

Table 4 presents the coefficients, statistical significance, and odds ratios (ORs) of the model fitting the 2008 data.

After controlling for the covariates in the model, the effect of the variable age is much the same as the effect found in the 2001 data. Accordingly, 1 more year of age decreases the odds of being in all five groups relative to the very rich group, by $9 \%$ in the extremely poor group to $1 \%$ in the rich group.

As in 2001, the variable sex is not statistically significant for the rich group. The odds of females being extremely poor relative to very rich are $60 \%$ higher than the odds for males, $40 \%$ higher for those in the vulnerable group, 19\% higher for those in the lowermiddle group, and $8 \%$ higher for those in the upper-middle group. Therefore, the effect decreases as one goes up the ladder of the relative income groups as in 2001 but becomes smaller compared to 2001.

As in 2001, among the ascribed variables, the variable race had a strong effect in 2008. Indeed, the odds of blacks being in the extremely poor group relative to the very rich group are 2.7 times higher than the odds for whites, 2.4 times higher for those in the vulnerable group, two times higher for those the lower-middle group, $62 \%$ higher

Table 4 Multinomial logistic regression of selected variables on the relative income groups-Northeast (NE) and Southeast (SE) regions, Brazil, 2008

\begin{tabular}{|c|c|c|c|c|c|c|c|c|c|c|}
\hline \multirow{3}{*}{$\begin{array}{l}\text { Intercept and } \\
\text { covariates }\end{array}$} & \multicolumn{10}{|c|}{ Income group $^{a}$} \\
\hline & \multicolumn{2}{|c|}{ Extremely poor } & \multicolumn{2}{|c|}{ Vulnerable } & \multicolumn{2}{|c|}{ Lower-middle } & \multicolumn{2}{|c|}{ Upper-middle } & \multicolumn{2}{|l|}{ Rich } \\
\hline & $b$ & OR & $b$ & OR & $B$ & OR & $b$ & OR & $b$ & OR \\
\hline Intercept & $6.511 *$ & - & $7.112^{*}$ & - & $5.384^{*}$ & - & $3.870^{*}$ & - & $1.695^{*}$ & - \\
\hline Age & $-0.099^{*}$ & .906 & $-0.075^{*}$ & .927 & $-0.046^{*}$ & .955 & $-0.030^{*}$ & .970 & $-0.011^{*}$ & .989 \\
\hline Sex: female (ref: male) & $0.505^{*}$ & 1.65 & 0.33 & 1.401 & $0.177^{*}$ & & $0.074^{*}$ & 1.077 & .045 & 1.047 \\
\hline Race: black (ref: white) & $0.983^{*}$ & 2.673 & $0.877^{*}$ & 2.403 & $0.700^{*}$ & 2.014 & $0.483^{*}$ & 1.622 & $0.253^{*}$ & 1.288 \\
\hline Years of schooling & $-0.516^{*}$ & .597 & $-0.417^{*}$ & .659 & $-0.318^{*}$ & .728 & $-0.223^{*}$ & .800 & $-0.098^{*}$ & .907 \\
\hline Region: NE (ref: SE) & $1.749 *$ & 5.750 & $1.073^{*}$ & 2.924 & $0.381^{*}$ & 1.464 & -.005 & .995 & $-0.166^{*}$ & .847 \\
\hline Area: rural (ref: urban) & $1.104^{*}$ & 3.016 & $0.476^{*}$ & 1.610 & $0.141^{*}$ & 1.151 & $-0.307^{*}$ & .735 & $-0.517^{*}$ & .597 \\
\hline
\end{tabular}

${ }^{a}$ Reference category, very rich

*Statistically significant at $p$ value $<0.01$ 
for those in the upper-middle group, and 29\% higher for those in the rich group. It is noticeable how the effect lessens from the extremely poor group up to the rich group. However, compared to 2001, the racial effect is somewhat attenuated.

Again, as in 2001, schooling decreases the odds of being in each of the five groups compared to the very rich group. In the case of the extremely poor group, each additional year decreases the odds by $40 \%$. This figure is $34 \%$ for the vulnerable group, $27 \%$ for the lower-middle group, $20 \%$ for the upper-middle group, and $9 \%$ for the rich group. The pattern of diminishing effect from the extremely poor group up to the rich group detected in 2001 is also present in 2008, and the dimension of the effect does not differ significantly from that found for 2001.

The coefficient of the variable region is not statistically significant for the uppermiddle group. For the three groups below this one, the coefficients are positive, while for the rich group, the coefficient is negative. Consequently, the odds of Northeasterners being in the extremely poor group relative to the very rich group are 5.75 times higher than the odds for Southeast dwellers, 2.9 times higher for those in the vulnerable group, and $45 \%$ higher for those in the lower-middle group. For the rich group, the odds are $15 \%$ lower relative to the Southeast residents belonging to the very rich group. The comparison between groups reveals the same pattern of diminishing effect as one goes up the income group ladder. Regarding the extremely poor and vulnerable groups, as in 2001, the variable region has the largest effect in holding down individuals in poverty and vulnerability, but the effect weakens in comparison with those in 2001.

With respect to area of residence, the coefficients are statistically significant for the five groups. The reverse effect from the lower-middle to upper-middle group observed in 2001 is also present. The odds of rural dwellers being in the extremely poor group relative to the very rich group are three times higher than the odds for urban dwellers, $61 \%$ higher in the case of the vulnerable group, and 15\% higher for those in the lowermiddle group. As for the upper-middle and rich groups compared to the very rich group, the odds are $26 \%$ and $40 \%$ lower, respectively. This finding indicates that individuals pertaining to these two groups living in rural areas tend to be wealthier than their urban counterparts. It is worth noting that the odds ratios for this variable are larger than those found in 2001, which is not observed in the case of the other variables.

Table 5 presents the coefficients, statistical significance, and odds ratios (ORs) of the model fitting the 2015 data.

Controlling for the covariates in the model, age has the same effect as observed in 2001 and 2008. One additional year of age decreases the odds of being in all five groups relative to the very rich group.

As in 2001 and 2008, the coefficient of the variable sex for the rich group is not statistically significant. The odds of females being in the extremely poor group relative to the very rich group are $98 \%$ higher than the odds for males, 59\% higher for those in the vulnerable group, 31\% higher for those in the lower-middle group, and 13\% higher for those in the upper-middle group. The pattern of diminishing effect across groups is present, but the odds ratios increase relative to those of 2008 and return to the levels of 2001.

Additionally, as in 2001 and 2008, the variable race shows the most significant effect among the ascribed variables in all five groups. Indeed, the odds of blacks being in the extremely poor group relative to the very rich group are 3.1 times higher than the odds 
Table 5 Multinomial logistic regression of selected variables on the relative income groups-Northeast (NE) and Southeast (SE) regions, Brazil, 2015

\begin{tabular}{|c|c|c|c|c|c|c|c|c|c|c|}
\hline \multirow{3}{*}{$\begin{array}{l}\text { Intercept and } \\
\text { covariates }\end{array}$} & \multicolumn{10}{|c|}{ Income group ${ }^{a}$} \\
\hline & \multicolumn{2}{|c|}{ Extremely poor } & \multicolumn{2}{|c|}{ Vulnerable } & \multicolumn{2}{|c|}{ Lower-middle } & \multicolumn{2}{|c|}{ Upper-middle } & \multicolumn{2}{|l|}{ Rich } \\
\hline & $b$ & OR & $b$ & OR & $b$ & OR & $b$ & OR & $b$ & OR \\
\hline Intercept & $7.240^{*}$ & - & $7.885^{*}$ & - & $6.183^{*}$ & - & $4.564^{*}$ & - & $1.886^{*}$ & - \\
\hline Age & $-0.097^{*}$ & .908 & $-0.071^{*}$ & .931 & -0.041 & .959 & $-0.026^{*}$ & .974 & $-0.008^{*}$ & .992 \\
\hline Sex: female (ref: male) & $0.685^{*}$ & 1.984 & $0.466^{*}$ & 1.594 & $0.269^{*}$ & 1.309 & $0.125^{*}$ & 1.134 & .035 & 1.036 \\
\hline Race: black (ref: white) & $1.146^{*}$ & 3.145 & $1.003^{*}$ & 2.726 & .846 & 2.330 & $0.655^{*}$ & 1.925 & $0.345^{*}$ & 1.412 \\
\hline Years of schooling & $-0.523^{*}$ & .593 & $-0.436^{*}$ & .646 & $-0.355^{*}$ & .701 & $-0.254^{*}$ & .776 & $-0.105^{*}$ & .900 \\
\hline Region: NE (ref: SE) & $1.722^{*}$ & 5.595 & $1.041^{*}$ & 2.832 & $0.524^{*}$ & 1.690 & .030 & 1.031 & .003 & 1.003 \\
\hline Area: rural (ref: urban) & $0.807^{*}$ & 2.241 & $0.138^{* *}$ & 1.148 & $-0.163^{*}$ & .849 & -0.540 & .583 & $-0.754^{*}$ & .471 \\
\hline
\end{tabular}

${ }^{a}$ Reference category, very rich

*Statistically significant at $p$ value $<0.01$

**Statistically significant at $p$ value $<0.05$

for whites, 2.7 times higher for those in the vulnerable group, 2.3 times higher for those in the lower-middle group, 93\% higher for those in the upper-middle group, and $41 \%$ higher for those in the rich group. The pattern of diminishing effect across groups is clear. Nevertheless, compared to 2008, the odds ratios for all groups increase, returning to the levels of 2001.

As seen both in 2001 and 2008, in 2015, schooling decreases the odds of being in each of five groups compared to the very rich group. As for the extremely poor group, each additional year decreases the odds by $41 \%$. This figure is $35 \%$ for the vulnerable group, $30 \%$ for the lower-middle group, $22 \%$ for the upper-middle group, and $10 \%$ for the rich group. In addition to presenting the same pattern of diminishing effects from the extremely poor up to the rich group, the 2015 results do not differ significantly from those found in 2001 and 2008.

The coefficients of the variable region are not statistically significant for the uppermiddle and rich groups in 2015. The odds of Northeasterners being in the extremely poor group relative to the very rich group are 5.6 times higher than the odds for Southeast dwellers, which is very close to the odds for 2008. Regarding the vulnerable group, the odds are 2.8 times higher for Northeast inhabitants versus Southeasterners, which is also very close to the 2008 odds for this group, and the odds are $69 \%$ higher in the lower-middle group. The comparison between groups reveals the same pattern of diminishing effect as one goes up the income group ladder anew. Regarding the extremely poor and vulnerable, as in 2001 and 2008, the variable region has the strongest withholding power over individuals in poverty and facing vulnerability.

With respect to area of residence, the coefficients are statistically significant for the five groups, but the reverse effect observed in 2001 and 2008 occurs only in the lowermiddle group. Accordingly, the odds of rural dwellers being in the extremely poor group relative to the very rich group are 2.2 times higher than the odds for urban dwellers, and $15 \%$ higher in the case of the vulnerable group. Regarding the lowermiddle group, rural dwellers are 15\% less likely to be in this group relative to the very rich group than are urban dwellers. Regarding the upper-middle and rich groups, compared to the very rich group, the odds are $42 \%$ and $53 \%$ smaller, respectively. However, again, as in 2001 and 2008, these results indicate that individuals of the top two groups 
living in rural areas tend to be the wealthiest. The odds ratios for this variable in 2015 are, on average, $24 \%$ smaller compared to 2008 and $8 \%$ smaller than compared to 2001.

To sum up the results, the variables with the largest effects are race (black versus white) and region (Northeast versus Southeast), specifically for the extremely poor and vulnerable groups. The influence of these two variables is related to the pattern of diminishing effects across groups from the bottom, extremely poor, to the top, rich, relative to the very rich group, evident in the data of 3 years analyzed for all variables, except age.

Across the three surveys, comparing the odds ratios of the same group between 2001 and 2008, one observes a decline in the magnitude of the effect in the case of the variables sex, race, and region and stability in the case of the variables age and years of schooling. In this regard, there were important gains between 2001 and 2008. The only variable that presents a decreased effect is area of residence, possibly reflecting the worsening conditions in rural areas compared to urban areas. Nevertheless, the odds ratios of all variables in 2015 are very close to those in 2001, except for area of residence. The odds ratios of area of residence in 2015 are, on average, 8\% lower than those in 2001. Regardless of the rural-urban exception, this is an important finding that supports the argument that the gains achieved between 2001 and 2008 were lost between 2008 and 2015. In other words, there was a return to the past.

\section{Conclusions}

In view of the findings of this study, we would like to highlight some results that stand out from the performed analyses. The considerable stability observed in the distribution of income groups in the 3 years 2001, 2008, and 2015 is noteworthy. Despite the claims about the rise of income, in Brazil, the decline of inequality is not observed regarding income groups or income categories. We found a slight decrease in the size of the top two income groups, rich and very rich; thus, we may be observing downward mobility toward the middle-income groups.

Nevertheless, as stated in the previous sections, the multinomial models show a decline in the odds ratio of the same group between 2001 and 2008 for sex, race, and region. The results indicate a tendency toward more equality during this period. Conversely, the effects of age and years of schooling remained stable. In contrast to the findings for the time interval 2001-2008, in 2015, the odds are quite similar to those estimated for 2001 for all variables, except for area of residence (urban versus rural). It is an important finding that allows us to argue that the advances achieved between 2001 and 2008 were overturned in the following 7 years between 2008 and 2015. Thus, considering sex, race, and region, economic inequality in Brazil was decreasing from 2001 to 2008, but in 2015, the odds for these factors returned to their levels in 2001, indicating a loss in the gains of minorities, as women, blacks and rural residents. In other words, Brazil went backward to the beginning of the twenty-first century.

Second, among the factors analyzed, regional inequality is by far the most conspicuous. Although regional inequalities are well documented in the Brazilian stratification literature of the 1960s, 1970, and 1980s, the theme seems to be out of sight in most recent studies in the field. Nonetheless, our analysis shows a noteworthy disparity between the two most populated regions-Southeast and Northeast, the latter showing a substantial concentration of the population in the lower-income categories. It is 
important to state that regional difference is a crucial research subject since it is a powerful determinant for political and electoral outcomes in Brazil.

The multinomial models confirm the extent of regional unbalance since region and race were the most significant variables in the three surveys. Race and region have the largest effects, which indicate that discrimination strongly marks inequalities once blacks and Northeasterners are the main targets of prejudice and intolerance in the country. Brazilian sociology has vastly exposed that these prejudices are rooted in our history (Vaitsman 2002).

Third, the results also indicate that generational inequalities remained stable and that the youngest individuals remained disadvantaged in the 3 survey years.

Fourth, considering the time intervals of 2001-2008 and 2008-2015, the effect of education did not change the income stratification structure, although there was an increase in years of schooling in Brazil during the period, as shown in Fig. 2. We are aware that education is a complex issue, especially considering the enormous gaps between school systems. However, we can argue that the increase in the number of years of schooling did not diminish the inequalities among income groups, even in the context of the educational expansion that occurred in recent decades.

In sum, our analysis sheds new light on income inequality during the first 15 years of the twenty-first century in Brazil. The results indicate that there was no significant change in the income structure and thus do not support the claims that Brazil has become a less unequal country. In this sense, it is even more difficult to agree with the thesis that Brazil has become a middle-class country. Although there had been advances from 2001 to 2008 toward an inequality reduction among the relative income categories, they were not profound and wide enough to withstand the economic backlash. When this backlash happened, the advancements obtained during the first decade of the century faded. In this respect, our study highlights how living standards in Brazil are dependent on economic growth and underscores the fact that only rises in income and consumption are insufficient to change the stratification structure and make a country less unequal.

\section{Appendix}

\section{Data and method}

We apply multinomial logistic regression analysis on data from 2001, 2008, and 2015 Brazilian National Household Survey, carried out annually. We employ multinomial logistic regression models to assess the effect of age, sex, race, years of schooling, region, and area of residence on the odds ratio of being in the extremely poor, vulnerable, lower-middle, upper-middle, and rich groups, with the very rich group as a reference.

Since the multinomial regression model is an extension of the binary logit model and is rooted in the analysis of association through odds ratio (Bohrnstedt and Knoke 1994), let us initiate with the case of variable $Y$ with two response categories and no covariates. In this case, the odds of $Y=1$ are

$$
O_{Y=1}=\frac{p_{Y=1}}{1-p_{Y=1}}
$$

Taking the logarithm of the odds, we transform it into the logit; that is, 


$$
\operatorname{logit}\left(p_{Y=1}\right)=\log \left(\frac{p_{Y=1}}{1-p_{Y=1}}\right)
$$

Let us now introduce an independent variable $X$ with two response categories. The probabilities of $Y=1$ controlling for each category of $X$ are

$$
\begin{aligned}
& p_{1}=P(Y=1 \mid X=1) \\
& p_{2}=P(Y=1 \mid X=0)
\end{aligned}
$$

In this case, the binary logistic model is

$$
\operatorname{logit}\left(p_{Y=1}\right)=\alpha+\beta x
$$

so that for $Y=1$ and $X=1$,

$$
\operatorname{logit}\left(p_{Y=1}\right)=\alpha+\beta(1)=\alpha+\beta
$$

and for $Y=1$ and $X=0$,

$$
\operatorname{logit}\left(p_{Y=1}\right)=\alpha+\beta(0)=\alpha
$$

The odds ratio (OR) relates two odds. In this case, the first is for $Y=1$ when $X=1$, and the second is for $Y=1$ when $X=0$, so that

$$
O R=\frac{O_{1}}{O_{2}}=\frac{\frac{p_{y=1 \mid x=1}}{1-p_{y=1 \mid x=1}}}{\frac{p_{y=1 \mid x=0}}{1-p_{y=1 \mid x=0}}}=\frac{\alpha+\beta}{\alpha}=\beta
$$

As the odds ratio on the left side of the binary logistic equation is transformed into logit by taking its logarithm, which is the right side of the equation. Both the odds in the numerator and the denominator of the OR turn into logit form:

$$
\begin{aligned}
& \operatorname{logit}_{y=1 \mid x=1}=\log \left(\frac{p_{y=1 \mid x=1}}{1-p_{y=1 \mid x=1}}\right) \\
& \operatorname{logit}_{y=1 \mid x=0}=\log \left(\frac{p_{y=1 \mid x=0}}{1-p_{y=1 \mid x=0}}\right)
\end{aligned}
$$

Thus, the odds ratio can be solved as subtraction of logits:

$$
\log (\mathrm{OR})=\operatorname{logit}_{y=1 \mid x=1}-\operatorname{logit}_{y=1 \mid x=0}=\beta
$$

To return to the odds domain, we exponentiate both sides of the equation

$$
\exp \left[\operatorname{logit}\left(p_{Y=1}\right)\right]=\exp (\alpha+\beta x)
$$

so that

$$
\frac{p_{Y=1}}{1-p_{Y=1}}=e^{\alpha+\beta x}
$$

Thus, $e^{\beta}$ is the odds of $Y=1$ when $X=1$ relative to the odds of $Y=1$ when $X=0$, that is, the odds ratio (Bohrnstedt and Knoke 1994). The logistic regression model with two or more covariates follows logically as an extension of the simple binary logistic regression model (Powers and Xie 2000). 
Now, let us consider the case of a dependent variable with $J>2$ categories. Letting $p_{i j}$ be the probability that individual $i$ falls into category $j$, the multinomial logistic regression model is as follows:

$$
\log \left(\frac{P_{i j}}{P_{i J}}\right)=\boldsymbol{\beta}_{j} \boldsymbol{x}_{i}
$$

where $\boldsymbol{x}_{i}$ is a column vector of independent variables related to individual $i$, and $\boldsymbol{b}_{j}$ is a row vector of coefficients for category $j$ of the dependent variable (Allison 1999). Each category $j$ is compared with the highest category $J$.

Once the coefficients are estimated, the comparison of any two categories of the dependent variable is achieved by subtracting the coefficient of the $j$ th category from the coefficient of the reference category (Allison 1999). Letting the highest category $J$ be the reference, the logit equation for comparison is

$$
\log \left(\frac{P_{i j}}{P_{i J}}\right)=\left(\boldsymbol{\beta}_{j}-\boldsymbol{\beta}_{J}\right) \boldsymbol{x}_{i}
$$

We analyze a subsample with individuals in the age bracket of 24-65 years old and inhabitants of the Northeast and Southeast regions. For the variable sex, females are the category of interest, and males are the reference category. The variable race contrasts black individuals relative to white individuals; the variable region compares Northeast (NE) inhabitants relative to Southeast (SE) inhabitants, and the variable area of residence compares rural dwellers with urban dwellers. Years of schooling and age are discrete variables.

\section{Abbreviations}

IBGE: Brazilian Institute of Geography and Statistics; IPEA: Institute for Applied Economic Research; PNAD: The National Household Sample Research

\section{Acknowledgements}

We would like to acknowledge the Federal University of Rio de Janeiro (UFRJ) and the Pontifical Catholic University of Minas Gerais (PUCMG) for offering institutional support to the authors. We also would like to thank Professor Mike Savage, Professor Li Peilin, and Professor Chunling Li for their valuable comments, as well as Professor Sin Yi Cheung and Professor Elisio Estanque for their support to the research.

\section{Authors' contributions}

All authors contributed for the data analysis and interpretation. Celi Scalon and Andre Junqueira Caetano were primarily responsible for the theoretical framework. The authors read and approved the final manuscript.

\section{Authors' information}

Celi Scalon is Full-Professor at the Federal University of Rio de Janeiro (UFRJ) and visiting scholar at the University of Coimbra (CES-Universidade de Coimbra), celiscalon@gmail.com.

André Junqueira Caetano is Professor at the Pontifical Catholic University of Minas Gerais (PUCMG), acaetano@pucminas.br.

Hugo Chaves is MA student at Stanford University, hugocdoa@gmail.com.

Luana Costa is MA student at the Federal University of Rio de Janeiro, luanasbcosta@gmail.com.

\section{Funding}

This study was financed by the Coordenação de Aperfeiçoamento de Pessoal de Nível Superior-Brazil (CAPE S) - finance code 001, The Brazilian National Council for Scientific and Technological Development (CNPq), and Carlos Chagas Filho Foundation for Supporting Research in the State of Rio de Janeiro (FAPERJ).

\section{Availability of data and materials}

The data supporting our findings are from The National Household Sample Research (PNAD), a survey carried by the Brazilian Institute of Geography and Statistics; it is publicly available and can be downloaded at https://www.ibge.gov. br/pt/inicio.html. 


\section{Author details}

${ }^{1}$ Federal University of Rio de Janeiro (UFRJ), Rio de Janeiro, Rio de Janeiro, Brazil. ${ }^{2}$ University of Coimbra (CES-Universidade de Coimbra), Coimbra, Portugal. ${ }^{3}$ Pontifical Catholic University of Minas Gerais (PUCMG), Belo Horizonte, Brazil. ${ }^{4}$ Stanford University, Stanford, CA, USA.

Received: 3 February 2020 Accepted: 14 October 2020

Published online: 04 January 2021

\section{References}

Allison, P.D. 1999. Logistic regression using the SAS system: theory and application. Cary: SAS Institute Inc.

Araújo, V., and P. Flores. 2017. Redistribuição de renda, pobreza e desigualdade territorial no Brasil. Revista de Sociologia e Política 25: 159-182.

Barros, R.; Carvalho, M.; Franco, S.; Mendonça, R. (2010) - Determinantes da Queda na Desigualdade de Renda no Brasil. IPEA. Texto para discussão n 1460 .

Bohrnstedt, G., E. and Knoke, D. 1994. Statistical for social data analysis. Illinois: Peacock Publishers.

Caetano, A.J., and J.G. Dias. 2018. Socioeconomic classification of the working-age Brazilian population: a joint latent class analysis using social class and asset-based perspectives. Social Indicators Research 139: 119-146.

Ferreira, L.H.S., and A.J. Caetano. 2015. Mercado de trabalho e informalidade no setor calçadista: um estudo comparado entre três municípios brasileiros nos anos 2000 e 2010. Trabalho \& Educação (UFMG). Vol. 24, 203-219.

Lélis, M.T.C., A.M. Cunha, and P. Linck. 2019. O choque nos preços das commodities e a economia brasileira nos anos 2000. Brazilian Journal of Political Economy 39: 427-448.

Li, P. (2017), China's path to overcoming the double middle-income traps. China \& World Economy, 25: 28-44.

Neri, Marcelo. 2008. A Nova Classe Média. Rio de Janeiro/RJ: CPS.

Neri, M. (2010) - O lado brilhante da pirâmide. Revista de Conjuntura, 64, (10): 58-61

Oliveira, Fabiana Luci. 2010. Movilidad Social y Económica en Brasil: ¿una nueva clase media? In Las Clases Medias en América Latina: retrospectiva y nuevas tendencias. Siglo xxi editores, CEPAL, ed. R. Franco, M. Hopenhayn, and A. León.

Powers, D.A., and Y. Xie. 2000. Statistical methods for categorical data analysis. San Diego: Academic.

Salata, A. 2016. A Classe Média Brasileira: posição social de classe. Rio de Janeiro: Letra Capital.

Salata, A., and C. Scalon. 2013. The formation of the middle class in Brazil: history and prospects. In Handbook on Social Stratification in the BRIC Countries, ed. L. Peilin, C. Scalon, M. Gorshkov, and K. Sharma, vol. 1, 1st ed., 339-357. Singapore/ London/ New Jersey: World Scientific.

Salata, A., and C. Scalon. 2015. Do Meio à Classe Média: como a "nova classe média" e a "classe média tradicional" percebem sua posição social? Ciências Sociais Unisinos. 51. https://doi.org/10.4013/csu.2015.51.3.14.

Santos Pinto, J., and A.J. Caetano. 2013. A Heterogeneidade da Vulnerabilidade Social das Juventudes: Uma Perspectiva Empírica Através do Método Grade Of Membership. Mediações - Revista de Ciências Sociais 18: 164-181.

Scalon, C. 2013a. Social stratification and its transformation in Brazil. In Handbook on social stratification in the BRIC countries change and perspective, ed. L. Peilin, C. Scalon, M. Gorshkov, and K. Sharma, vol. 1, 1st ed., 3-19. Singapore/ London/ New Jersey: World Scientific.

Scalon, C. 2013b. Juventude, Igualdade e Protestos. Revista Brasileira de Sociologia 01: 179-204.

Scalon, C., and P.P. Oliveira. 2018. Social justice, development and youth: professor Modi and an encounter between Indian and Brazilian sociology. In Issues and themes in contemporary society, ed. B.K. Nagla Vinay and Kumar Srivastava, vol. 1, 1st ed., 3-13. New Delhi: Rawat Publications.

Scalon, C. and Salata, A. (2012) - Uma nova classe média no Brasil da última década? O debate a partir da perspectiva sociológica. Sociedade e Estado, 27 (2).

SCALON, C. (2013). Social stratification and its transformation in Brazil. In: Peilin, L; Scalon, C.; Gorshkov M., Sharma K. (Org.). Handbook on Social Stratification in the BRIC Countries Change and Perspective. 1ed.Singapore/ London/ New Jersey: World Scientific, 2013, 1: 3-19.

Serrano, F., and R. Summa. 2018. Conflito distributivo e o fim da breve era de ouro da economia brasileira. Novos estudos CEBRAP 37: 175-189.

Silva, G.M., and L.T.d.S. LEÃO. 2012. O paradoxo da mistura: identidades, desigualdades e percepção de discriminação entre brasileiros pardos. Revista Brasileira de Ciências Sociais 27: 117-133.

Silva, J., and De Oliveira. 2019. A distopia do mérito: desigualdades escolares no Ensino Médio brasileiro analisadas a partir do ENEM. (Dissertation). Faculdade de Educação, Universidade Estadual de Campinas.

Souza, A., and Bolívar Lamounier. 2010. A Classe Média Brasileira: ambições, valores e projetos de sociedade. Rio de Janeiro/RJ: Elsevier

Souza, Jessé. 2010. Os batalhadores brasileiros. Nova classe média ou nova classe trabalhadora? Belo Horizonte: UFMG.

Souza, P., and M. Medeiros. 2015. Top income shares and inequality in Brazil, 1928-2012. Sociologies in Dialogue 1 (1): 119-132 jul-dez 2015.

Vaitsman, J. 2002. Desigualdades sociais e duas formas de particularismo na sociedade brasileira. Cadernos de Saúde Pública 18: S37-S46.

\section{Publisher's Note}

Springer Nature remains neutral with regard to jurisdictional claims in published maps and institutional affiliations. 